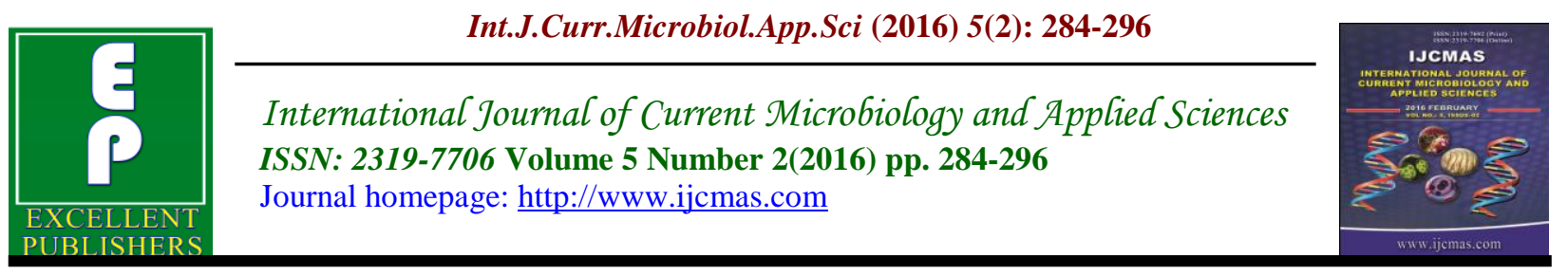

Original Research Article

doi: http://dx.doi.org/10.20546/ijcmas.2016.502.033

\title{
Isolation of Lactobacillus curvatus KNOUC4148 from Kimchi and Its Properties as a Probiotic
}

\author{
E. S. $\operatorname{Nam}^{1}$ and J. K. $\mathrm{Ahn}^{2} *$ \\ ${ }^{1}$ Sogang-Binggrae Food Advanced Analysis Center, Sogang University, \\ Seoul 121-742, Republic of Korea \\ ${ }^{2}$ Department of Agricultural Sciences, Korea National Open University, \\ Seoul 110-791, Republic of Korea \\ *Corresponding author
}

\begin{tabular}{|c|c|}
\hline & A B S T R A C T \\
\hline $\begin{array}{l}\text { Ke y w o r d s } \\
\text { Kimchi, } \\
\text { antimicrobial } \\
\text { substance, } \\
\text { Lactobacillus } \\
\text { curvatus } \\
\text { KNOUC4148. }\end{array}$ & $\begin{array}{l}\text { This study was to screen lactic acid bacteria useful for probiotics from a } \\
\text { Korean fermented food, kimchi. A strain KNOUC } 4148 \text { was selected and } \\
\text { identified phenotypically and genotypically as Lactobacillus }(\text { Lb. }) \text { curvatus, } \\
\text { and named as } L b \text {. curvatus KNOUC4148. The strain showed acid tolerance } \\
\text { retaining viability of } 4.82 \log _{10} \mathrm{CFU} / \mathrm{ml} \text { among initial } 8.15 \log _{10} \mathrm{CFU} / \mathrm{ml} \\
\text { after treatment at } \mathrm{pH} 2 \text { for } 120 \mathrm{~min} \text {. Oxgall added in MRS broth at the } \\
\text { concentration of } 3 \% \text { did not inhibit the growth of Lb. curvatus } \\
\text { KNOUC4148. Cell surface hydrophobicity of Lb. curvatus KNOUC4148 } \\
\text { was } 71.89-86.25 \% \text { to organic solvents of hexadecane, toluene and xylene. }\end{array}$ \\
\hline Article Info & The antimicrobial activity of antimicrobial substance produced by the isolate \\
\hline $\begin{array}{l}\text { Accepted: } \\
\text { 15 January } 2016 \\
\text { Available Online: } \\
\text { 10, February } 2016\end{array}$ & $\begin{array}{l}\text { kept unchanged through acidic or alkaline treatment of } \mathrm{pH} 2 \text { to } \mathrm{pH} 10 \text {, and } \\
\text { heat treatment at } 30^{\circ} \mathrm{C} \text { to } 100^{\circ} \mathrm{C} \text { for } 30 \mathrm{~min} \text { and at } 121^{\circ} \mathrm{C} \text { for } 15 \mathrm{~min} \text {. The } \\
\text { antimicrobial substance of KNOUC } 4148 \text { lost completely its antimicrobial } \\
\text { activity by proteolytic and amylolytic hydrolysis. SDS-PAGE analysis } \\
\text { revealed an apparent antimicrobial substance. }\end{array}$ \\
\hline
\end{tabular}

\section{Introduction}

Kimchi, a Korean traditional fermented vegetable food made of vegetables and seasonings including napa cabbage, radish, hot red pepper, green onion, garlic and ginger, is recognized as functional food due to its beneficial effects on human health derived from components in raw materials, fermentation products and lactic acid bacteria (LAB) ( Kim et al., 2011).
Particularly LAB are attracting interest for immune stimulation, pathogen exclusion, production of bioactive substances and general intestinal health (Naidu et al., 1999). In addition, LAB impart a characteristic flavor to fermented foods (Lui et al., 2008) and increase their shelf life by protecting foods from many kind of bacteria including putrefactive bacteria by producing inhibitory 
agents such as organic acids, hydrogen peroxide, ethanol, reuterin and bacteriocin(Ross et al., 2002). Especially $\mathrm{LAB}$ bacteriocin has possibilities to prevent the development of specific unwanted spoilage and pathogenic bacteria in both of fermented and non-fermented foods because of their broad- or narrow-host-range specificity(Ross et al., 2002). LAB bacteriocins were produced by $L b$., Lactococcus, Streptococcus, Enterococcus, Pediococcus and Leuconostoc spp. (Naidu et al., 1999: Todorov et al., 2011). Regarding the application of bacteriocin-producing starter strains in food fermentation, the major problem is related to the in situ antimicrobial efficacy which can be negatively influenced by various factors, such as binding of the bacteriocins to food components (fat or protein particles) and food additives(egg, triglyceride oils), inactivation by proteases or other inhibitors, changes in solubility and charge, and changes by the cell envelope of target bacteria(Aasen et al., 2003: Leroy and De Vuyst, 1999).

Kimchi is growing in popularity throughout the world partly because of its LAB inhibiting intestinal pathogens. LAB producing bacteriocin in kimchi are targeted to be investigated(Han et al., 2013), and it is necessary to find more $\mathrm{LAB}$ producing antimicrobial substance to explain the function of kimchi and to get $\mathrm{LAB}$ useful for probiotics and food industry. Accordingly this study was to screen and identify LAB producing bacteriocin like antimicrobial substance from kimchi and to characterize the properties of the isolate as a probiotic.

\section{Materials and Methods}

\section{Isolation of lactic acid bacteria producing antimicrobial substance}

Kimchi samples, baechu kimchi and kkakdugi available at local markets in
Korea, were homogenized, serially diluted ten-fold with saline solution, plated on MRS agar(Difco, Detroit, USA) containing Naazide $(0.02 \%)$, and incubated statically at $37^{\circ} \mathrm{C}$ for 2-3 days. Colonies formed on MRS agar were randomly selected and propagated until the pure cultures were obtained. The isolates of Gram reaction positive, catalase negative, and non-spore former were recognized as presumptive $\mathrm{LAB}$, and chosen for further study. The antimicrobial activities in cell free culture supernatants of LAB isolated were tested by modified triphenyltetrazolium chloride(TTC) test (Summanen et al., 1992) and paper disc diffusion method (Hernnadez et al., 2005). Cell free culture supernatants were prepared by centrifugation $\left(7,500 \times \mathrm{g}, 5 \mathrm{~min}, 4^{\circ} \mathrm{C}\right)$ of culture grown in MRS broth statically at $37^{\circ} \mathrm{C}$ for $48 \mathrm{~h}$, and filtered through Millipore membrane filters $(0.45 \mu \mathrm{m}$ pore $)$ after the $\mathrm{pH}$ of the supernatants was adjusted to $\mathrm{pH} 7.0$ with $1 \mathrm{~N} \mathrm{NaOH}$. TTC test was performed against Staphylococcus aureus, Bacillus cereus and Escherichia coli.

Those indicator strains cultured in trypticase soy broth was added to the cell free culture supernatants containing tetrazolium $\operatorname{red}(0.2 \%)$, incubated for $16 \mathrm{~h}$ at $37^{\circ} \mathrm{C}$, and antimicrobial activity against those indicator strains was identified by invariance of tetrazolium red color. For the test of antimicrobial activity on paper disc diffusion method, Listeria monocytogenes was used as the indicator strain. Tryptic soy soft agar( $(0.7 \%$, w/v) inoculated with $1 \%(\mathrm{v} / \mathrm{v})$ of Listeria monocytogenes overnight culture, was overlaid on tryptic soy agar $1.5 \%(\mathrm{w} / \mathrm{v})$. Paper discs impregnated with the respective cell free culture supernatants and air dried were laid on the tryptic soy soft agar in a plate prepared above. The plate was incubated for $24 \mathrm{~h}$ at $37^{\circ} \mathrm{C}$, and examined for the formation of inhibition zone. 


\section{Identification of Isolated Strain}

Identification of the selected isolate was performed by morphological and biochemical properties, and 16S rDNA sequence. Morphological and biochemical properties were tested according to the criteria of Bergey's Manual of Determinative Bacteriology (Holt et al., 1994). Carbohydrate fermentation was studied using an API 50 CHI kit (Biomerieux, Lyan, France). The sequencing of $16 \mathrm{~S}$ rDNA was carried out by the method of Rainey et al.(1996) using the Big Dye terminator cycle sequencing kit (Applied Biosystems model 3730XL; Applied BioSystem). The 16S rDNA sequence of the strain was aligned to the 16S rDNA gene sequence of $\mathrm{LAB}$ and other related taxa in Genbank to compare the levels of similarity, and phylogenetic tree for the dataset was constructed by the neighbor-joining method (Saitou and Nei, 1987).

\section{Resistance of isolated strain to heat, acid and bile salt}

The isolated strain cultured in MRS broth for $24 \mathrm{~h}$ at $37^{\circ} \mathrm{C}$ statically, was heated at $50^{\circ} \mathrm{C}$ and $60^{\circ} \mathrm{C}$ for $30 \mathrm{~min}$. The number of viable cells were determined by plating the heat treated culture on MRS agar and incubating at $37^{\circ} \mathrm{C}$ for $48 \mathrm{~h}$. To determine the resistance to acidic conditions, viable cells were enumerated during incubation for $120 \mathrm{~min}$ at $37^{\circ} \mathrm{C}$ in MRS broth adjusted to pH 2.0 using $0.1 \mathrm{~N} \mathrm{HCl}$. Viable cell counts were performed by plating on MRS agar. To study the resistance to bile salt, effect of oxgall on the growth of the isolate was tested by the method described by Walker and Gilliland(Walker and Gilliland, 1993). Culture of the isolate was inoculated in MRS broth containing oxgall(Difco, Detroit, USA) added to the concentration of $0.3 \%$ $(w / v)$, and cultured at $37^{\circ} \mathrm{C}$. The growth at $37^{\circ} \mathrm{C}$ was monitored by $\mathrm{OD}_{600 \mathrm{~nm}}$ readings $\left(\mathrm{D}_{600}\right)$ up to $7 \mathrm{~h}$ using spectrophotometer.

\section{Cell surface Hydrophobicity of Isolated Strain}

Cells of the isolate grown at $37^{\circ} \mathrm{C}$ in LAPTg broth were harvested by centrifugation $\left(10,000 \times \mathrm{g}, 10 \mathrm{~min}, 4^{\circ} \mathrm{C}\right)$ at the early logarithmic growth phase(12-18 h of incubation), washed twice with physiological saline solution, resuspended in the same solution to the $\mathrm{D}_{600}$ of $0.5-0.7$, and used for assay. Cell surface hydrophobicity was determined by the adherence to solvents of hydrocarbon (hexadecane, toluene or xylene) by the method of Kiely and Olson(2000). One $\mathrm{ml}$ of hydrocarbon was added to the $3 \mathrm{ml}$ of washed cells in test tube.

The mixture was blended on a vortex mixer for $90 \mathrm{sec}$, then the tube was left statically for 15 min until phases of aqueous and hydrocarbon were separated, and $\mathrm{D}_{600}$ of the aqueous phase was measured. Hydrophobicity was calculated as the percentage decrease in the $\mathrm{D}_{600}$ of original bacterial suspension due to partitioning of cells into the hydrocarbon layer. Mycobacterium sp. was used as positive control and Lb. acidophilus CRL 730 as negative control. Hydrophobicity was indicated as \% microbial adhesion to organic solvents as follows.

$\%$ microbial adhesion to solvent $=\left[\left(\mathrm{D}_{600}\right.\right.$ of original suspension $-D_{600}$ of aqueous phase)/ $\mathrm{D}_{600}$ of original suspension] $\times 100$

Effect of heat, $\mathrm{pH}$ and enzymatic hydrolysis on antimicrobial activity of antimicrobial substance.

Cell free culture supernatant was used for assay, and antimicrobial activity was 
determined by disc diffusion method. To test the effect of heat, the cell free culture supernatant of the isolate was exposed to various temperatures at 30, 40, 50, 60, 70, 80,90 and $100^{\circ} \mathrm{C}$ for $30 \mathrm{~min}$, or autoclaved for $15 \mathrm{~min}$ at $121^{\circ} \mathrm{C}$, and the residual antimicrobial activity was tested. Resistance to various $\mathrm{pHs}$ was assayed at $\mathrm{pH} 2$ to $\mathrm{pH}$ 10. The cell free culture supernatant was adjusted to $\mathrm{pH} 2$ to $\mathrm{pH} 10$ using $1 \mathrm{~N} \mathrm{HCl}$ or $1 \mathrm{~N} \mathrm{NaOH}$ (Hernnadez et al., 2005), and was incubated for $1 \mathrm{~h}$ at $37^{\circ} \mathrm{C}$ at each $\mathrm{pH}$. After the incubation, $\mathrm{pH}$ of the cell free culture supernatant was neutralized to $\mathrm{pH} 7.0$ with $1 \mathrm{~N} \mathrm{HCl}$ or $1 \mathrm{~N} \mathrm{NaOH}$ and the residual antimicrobial activity was determined. To determine the influence of proteolytic and amylolytic enzymes on antimicrobial activity, cell free culture supernatant of the isolate was treated with proteinase $\mathrm{K}$, trypsin or $\alpha$-amylase(Sigma, St Louis, MO, USA) at $37^{\circ} \mathrm{C}$ for $2 \mathrm{~h}$. Proteinase $\mathrm{K}$ and trypsin were dissolved in tris- $\mathrm{HCl}(0.05 \mathrm{M}$, $\mathrm{pH}$ 8.0), $\alpha$-amylase was dissolved in $\mathrm{Na}$ phosphate buffer(0.1M, pH 7.0), and the enzyme solutions were filtered through Millipore membrane filter $(0.45 \mu \mathrm{m}$ pore $)$. All the enzymes were used at the final concentration of $1 \mathrm{mg} / \mathrm{ml}$. After hydrolysis, the mixture of enzyme and cell free culture supernatant of the isolate was heated at $80^{\circ} \mathrm{C}$ for $10 \mathrm{~min}$ to inactivate the enzymes, and assayed for residual antimicrobial activity.

\section{Confirmation of antimicrobial substance on SDS-PAGE gel}

The antimicrobial substance in cell free culture supernatant was confirmed by tricinSDS-PAGE(Schagger and Von Jagow, 1987), using concentration gel of $4 \%$ acrylamide and separation gel of $15 \%$ acrylamide. After electrophoresis of two identical samples, the gel was cut in two vertical ones of each sample. One was stained with Coomassie brilliant blue R-250, and the other one was assayed for antimicrobial activity against Listeria monocytogenes by the soft agar overlay method according to Bhunia et al.(1987) with modification. Briefly, the gel was fixed in the mixed aqueous solution of isopropanol(20\%) and acetic acid(10\%) for $2 \mathrm{~h}$, rinsed with distilled water(initial rinse for $1 \mathrm{hr}$. followed by two washes of $5 \mathrm{~min}$. each), and overlaid with $20 \mathrm{ml}$ of soft Muller Hinton agar $(0.7 \%)$ seeded with $10^{5}$ $\mathrm{CFU} / \mathrm{ml}$ of Listeria monocytogenes. After incubation at $37^{\circ} \mathrm{C}$ for $16 \mathrm{~h}$, the gel was examined for the presence of an inhibitory zone.

\section{Results and Discussion}

\section{Screening and Identification of LAB Producing Antimicrobial Substance}

Three hundred and fifty one isolates were taken from the kimchi samples. Among them, 196 isolates were screened as presumptive $\mathrm{LAB}$ by the properties of positive in Gram stain, non-spore formation, and negative in catalase activity. The 196 isolates were tested for antimicrobial activity by TTC test and paper disc diffusion assay. In the test of antimicrobial activity, isolates KNOUC4148 and KNOUC4149 showed high activity. Those two selected isolates were tested for biochemical properties. As in Table 1, isolates KNOUC4148 and KNOUC4149 were presumably identified as $L b$. curvatus and Leuconostoc mesenteroides respectively(Holt et al., 1994). The isolate KNOUC4149 produced $\beta$-glucuronidase catalyzing the hydrolysis of benzopyrene-3glucuronide to a benzopyrene derivative that is a carcinogenic substance( $\mathrm{Kim}$ and Jin, 2001), and the isolate KNOUC4148 was finally chosen and tested its $16 \mathrm{~S}$ rDNA sequence for further identification. In the phylogenetic tree generated by $16 \mathrm{~S}$ rDNA 
sequence (GenBank: KF411435), the isolate KNOUC4148 formed a distinct cluster with Lb. curvatus DSM20019 in $99.8 \%$ similarity(Figure 1). Therefore, the isolate was finally identified and named as $L b$. curvatus KNOUC4148. Many strains of $L b$. curvatus were isolated from sausages(Mataragas et al., 2002: Sudirman et al, 1993: Tichaczek et al., 1992: Verluyten et al., 2004), retail meats(Garver and Muriana, 1994), dairy food(Casla et al., 1996), fermented sausage(Mataragas et al., 2002: Verluyten et al., 2004) and kimchi (Ha et al., 1994: Kim et al., 1998).

\section{Properties of Isolate KNOUC4148 for Probiotic}

LAB stable at high temperature is advantageous for practical use, and microorganisms used as probiotics taken orally have to pass the acidic condition of pH 2 in stomach(Morelli, 2000), and bile salts of $0.1-0.3 \%$ in gastrointestinal track with residence time of about $4 \mathrm{~h}$ (Gunn, 2000) to arrive and colonize at intestinal surface. As in Table 2, among 8.68 $\log 10 \mathrm{CFU} / \mathrm{ml}$ of the strain KNOUC4148 heated at 50 and $60^{\circ} \mathrm{C}$ for $30 \mathrm{~min}, 8.41$ $\log 10 \mathrm{CFU} / \mathrm{ml}$ and $7.30 \quad \log 10 \mathrm{CFU} / \mathrm{ml}$ survived respectively, showing fair stability. In the acid tolerant test, among initial 8.15 $\log 10 \mathrm{CFU} / \mathrm{ml}, 6.27 \log 10 \mathrm{CFU} / \mathrm{ml}$ and 4.82 $\log 10 \mathrm{CFU} / \mathrm{ml}$ survived at $\mathrm{pH} 2.0$ in $60 \mathrm{~min}$ and $120 \mathrm{~min}$ respectively(Table 2). Oxgall of $0.3 \%$ in MRS broth did not affect the growth of isolate KNOUC4148(Figure 2). These acid and oxgall tolerance may suggest that Lb. curvatus KNOUC4018 will pass through the harsh gastric environment to intestinal track. To colonize at intestine, microorganism has to attach to intestinal surface. Cell hydrophobicity is one of factors that contribute to adhesion of bacterial cells to host tissues, and cell of higher hydrophobicity is likely to have more opportunity to inhabit in the human gastrointestinal tract(Naidu et al., 1999). In vitro determination of microbial adhesion to organic solvents of hexadecane, toluene and xylene droplets was carried out. This method was reported to be qualitatively valid to estimate the ability of microorganisms to adhere to epithelial cells(Kiely and Olson, 2000). Hydrophobicities of the isolate KNOUC4148 to hexadecane, toluene and xylene were $71.89 \%, 81.95 \%$ and $86.25 \%$ respectively as shown in Figure 3 . Hydrophobicity of $L b$. curvatus KNOUC4148 was higher than those of $L b$. fermentum(78.9\%), Lb. delbrueckii(43.7\%), Pediococcus acidilactici(51.3\%), and $L b$. rhamnosus GG(53.3\%)(Todorov et al., 2011). Surface proteins and lipoteichoic acids were reported to confer hydrophobic properties to the cellular surface of several strains of $L b$. sp.(Schar-Zammaretti and Ubbink, 2003), and hydrophobicity of cell surface could be enhanced by modifying the composition and $\mathrm{pH}$ of cultivation media(Ram and Chander, 2003).

\section{Properties of Antimicrobial Substance Produced by Isolate KNOUC4148}

Stability to heat and at wide range of $\mathrm{pH}$ is required for antimicrobial substance to be used in food industry. The antimicrobial substance produced by isolate KNOUC4148 in cell free culture supernatant showed excellent stability by maintaining full antimicrobial activity at the treatment for $30 \mathrm{~min}$ at 30 to $100{ }^{\circ} \mathrm{C}$ and at autoclaving for 15 min at $121^{\circ} \mathrm{C}$ (Figure 4 and Table 3). The bacteriocins produced by $L b$. curvatus DU0162 and DU0182 lost 50\% of activity in $30 \mathrm{~min}$ at $100{ }^{\circ} \mathrm{C}$ and were completely inactivated in $10 \mathrm{~min}$ at $121^{\circ} \mathrm{C}(\mathrm{Ha}$ et al., 1994). 
Table.1 Physiological and Biochemical Properties of Strain KNOUC4148 and KNOUC4149

\begin{tabular}{|c|c|c|c|c|c|}
\hline Characteristics & $\begin{array}{c}\text { KNOUC } \\
4148\end{array}$ & $\begin{array}{c}\text { KNOUC } \\
4149\end{array}$ & Characteristics & $\begin{array}{l}\text { KNOUC } \\
4148\end{array}$ & $\begin{array}{c}\text { KNOUC } \\
4149\end{array}$ \\
\hline Gram's stain &,+ rod &,+ cocci & 5keto-gluconate & - & - \\
\hline Catalase test & - & - & D-Glucose & + & + \\
\hline Oxidase test & - & - & D-Fructose & + & + \\
\hline \multirow[t]{2}{*}{ Spore formation } & - & - & D-Mannose & - & - \\
\hline & & & L-Sorbose & - & - \\
\hline Enzyme test & & & Rhamnose & - & - \\
\hline Alkaline phosphatase & - & + & Dulcitol & - & - \\
\hline Esterase & + & + & Inositol & - & - \\
\hline Esterase lipase & + & - & Mannitol & - & - \\
\hline Lipase & - & - & Sorbitol & - & - \\
\hline Leucine arylamidase & - & - & Methyl- $\alpha$-D-mannoside & - & - \\
\hline Valine arylamidase & - & - & Methyl- $\alpha$-D-glucoside & + & + \\
\hline Cytine arylamidase & - & - & N-Acetylglucosamine & - & - \\
\hline Trypsin & - & - & Amygdalin & - & - \\
\hline$\alpha$-chymotrypsin & - & - & Arbutin & + & - \\
\hline Acid phosphatase & + & + & Esculin & + & - \\
\hline $\begin{array}{l}\text { Naphtol-AS-BI- } \\
\text { phosphohydrolase }\end{array}$ & + & - & Salicin & + & - \\
\hline$\alpha$-galactosidase & - & + & Gluconate & - & - \\
\hline$\beta$-galactosidase & - & + & Xylitol & - & - \\
\hline$\beta$-glucoronidase & - & + & Lactose & - & + \\
\hline$\alpha$-glucosidase & + & + & Melibiose & - & + \\
\hline$\beta$-glucosidase & - & + & Saccharose & - & + \\
\hline $\mathrm{N}$-acetyl- $\beta$-glucosamidase & - & - & Trehalose & - & - \\
\hline$\alpha$-mannosidase & - & - & Inuline & - & - \\
\hline \multirow[t]{2}{*}{$\alpha$-fucosidase } & - & - & Melezitose & - & + \\
\hline & & & Galactose & + & + \\
\hline Carbohydrate utilization & & & Amidon & - & - \\
\hline Glycerol & - & - & $\beta$-Gentiobiose & - & - \\
\hline Erythriol & - & - & D-Raffinose & - & - \\
\hline D-Arabinose & - & + & D-Arabitol & - & - \\
\hline L-Arabinose & + & - & D-Turanose & - & - \\
\hline Ribose & + & + & D-Lyxose & - & - \\
\hline D-Xylose & - & - & D-Tagatose & - & - \\
\hline L-Xylose & - & - & D-Fucose & - & - \\
\hline Adonitol & - & - & L-Fucose & - & - \\
\hline$\beta$-Methyl-xyloside & + & - & L-Arabitol & - & - \\
\hline 2keto-gluconate & - & - & & & \\
\hline $\begin{array}{r}\text { Presumtive identification } \\
\text { KNOUC4148 } \\
\text { KNOUC4149 }\end{array}$ & $\begin{array}{l}\text { : Lactobaci } \\
: \text { Leuconost }\end{array}$ & $\begin{array}{l}\text { curvatus } \\
\text { esenteroi }\end{array}$ & & & \\
\hline
\end{tabular}


Table.2 Heat Stability and Acid Tolerance of Lactobacillus curvatus KNOUC4148

\begin{tabular}{lc}
\hline Treatment & $\begin{array}{c}\text { Viable cells } \\
\left(\log _{\mathbf{1 0}} \mathbf{C F U} / \mathbf{m l}\right)\end{array}$ \\
\hline Heat stability & \\
Control & $8.68 \pm 0.03$ \\
$50^{\circ} \mathrm{C}$ & $8.41 \pm 0.25$ \\
$60^{\circ} \mathrm{C}$ & $7.30 \pm 0.28$ \\
\hline Acid tolerance at $\mathbf{p H ~ 2 . 0}$ & \\
0 min. & $8.15 \pm 0.12$ \\
15 min. & $7.64 \pm 0.27$ \\
30 min. & $7.40 \pm 0.34$ \\
45 min. & $7.01 \pm 0.20$ \\
60 min. & $6.27 \pm 0.62$ \\
120 min. & $4.82 \pm 0.27$ \\
\hline
\end{tabular}

Table.3 Effect of Hydrolytic Enzymes, $\mathrm{pH}$ and Temperature on Antimicrobial Activity of the Antimicrobial Substance in cell Free Supernatant of Lactobacillus Curvatus KNOUC4148

\begin{tabular}{|c|c|c|}
\hline Treatment & & Antimicrobial activity \\
\hline Control & & $+^{1,2}$ \\
\hline Enzyme & $\alpha$-amylase & - \\
\hline & protease $\mathrm{K}$ & - \\
\hline & trypsin & - \\
\hline pH & 2 & $(+)$ \\
\hline (at $\left.37^{\circ} \mathrm{C}, 1 \mathrm{hr}\right)$ & 4 & + \\
\hline & 5 & + \\
\hline & 6 & + \\
\hline & 7 & + \\
\hline & 8 & $(+)$ \\
\hline & 10 & $(+)$ \\
\hline Temp. & $30^{\circ} \mathrm{C} 30 \mathrm{~min}$. & + \\
\hline (at pH 7.0) & $40^{\circ} \mathrm{C} 30 \mathrm{~min}$ & + \\
\hline & $50^{\circ} \mathrm{C} 30 \mathrm{~min}$. & + \\
\hline & $60^{\circ} \mathrm{C}$ 30min. & + \\
\hline & $70^{\circ} \mathrm{C}$ 30min. & + \\
\hline & $80^{\circ} \mathrm{C} 30 \mathrm{~min}$ & + \\
\hline & $90^{\circ} \mathrm{C} 30 \mathrm{~min}$. & + \\
\hline & $100^{\circ} \mathrm{C} 30 \mathrm{~min}$ & + \\
\hline & Autoclaving $\left(121^{\circ} \mathrm{C}, 15 \mathrm{~min}.\right)$ & + \\
\hline
\end{tabular}


Fig.1 Phylogenetic tree based on 16S rDNA sequences showing the positions of strain KNOUC4148, the type strains of Lactobacillus species and the representative of some other related taxa. Scale bar represents 0.02 substitution per nucleotide position

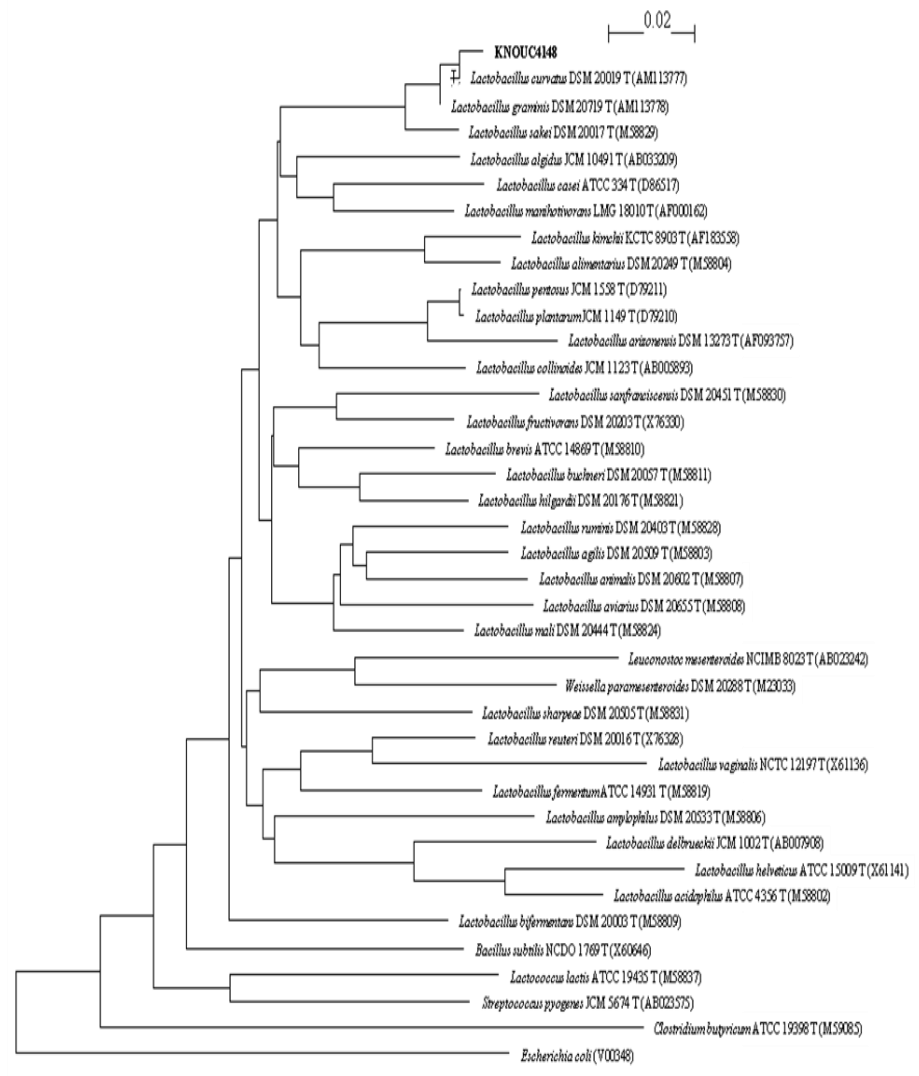

Fig.2 Effect of $0.3 \%$ oxgall in MRS Broth on Growth of Lactobacillus curvatus KNOUC4148 as Determined by OD at 600nm(D600)

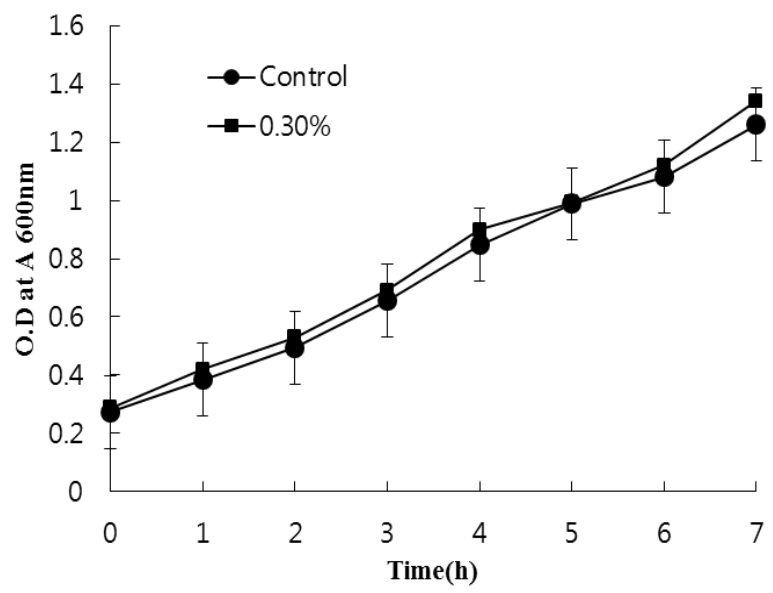


Fig.3 Hydrophobicity of Lactobacillus curvatus KNOUC4148 against various Solvents

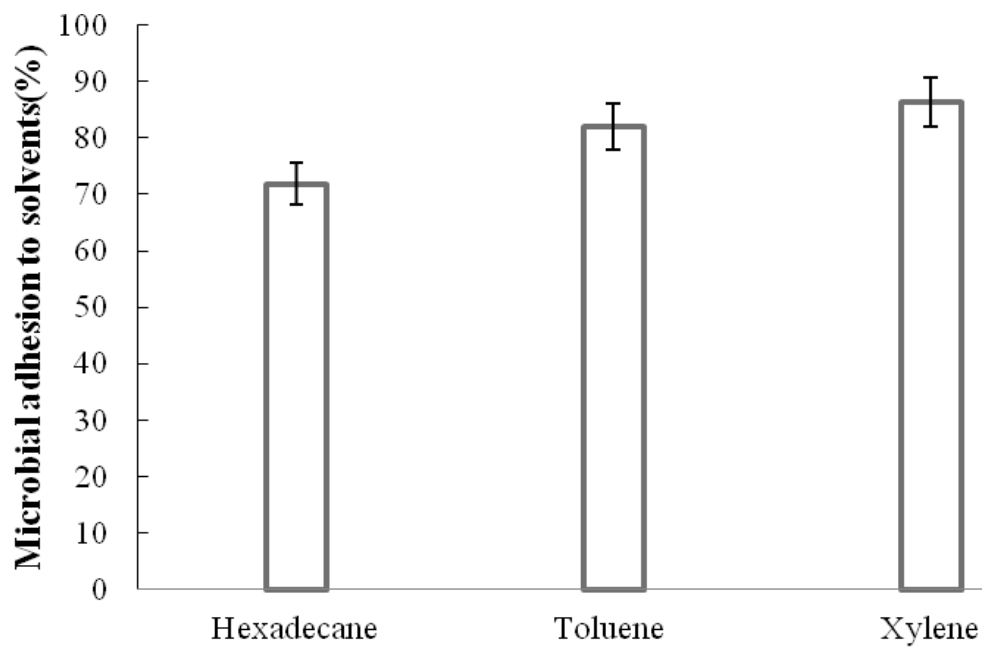

Solvents

*\% Microbial adhesion to solvent (hydrophobicity)

$=\left[\left(\mathrm{A}_{600}\right.\right.$ of original suspension $-\mathrm{A}_{600}$ of aqueous phase $) / \mathrm{A}_{600}$ of original suspension $] \times 100$

Fig.4 Antimicrobial Activity of Cell-free Supernatant of Lactobacillus curvatus KNOUC4148 against Listeria monocytogenes ATCC19117 by Agar well Diffusion Assay

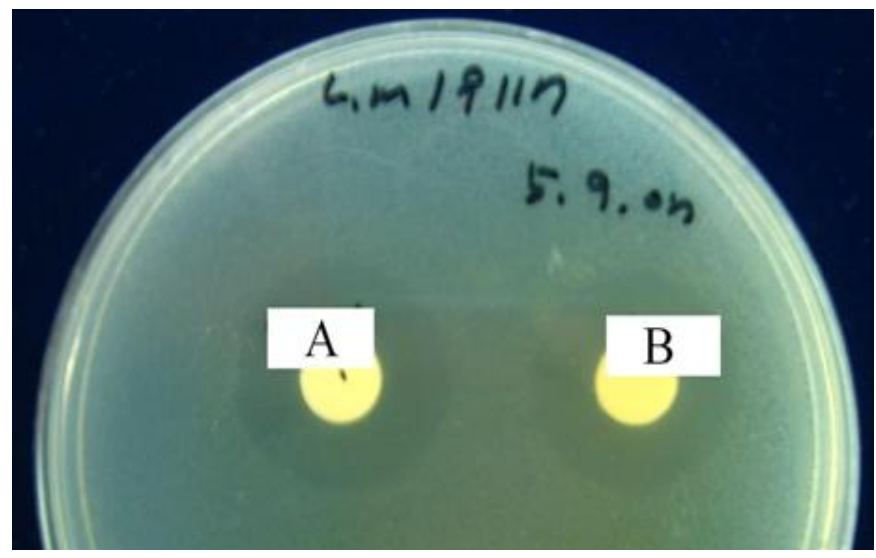

A: cell-free supernatant of Lactobacillus curvatus KNOUC4148

B: cell-free supernatant of Lactobacillus curvatus KNOUC4148 after heating at $100^{\circ} \mathrm{C}$ for $30 \mathrm{~min}$ 
Fig.5 SDS-PAGE and Antimicrobial Activity of the Cell-free Supernatant of Lactobacillus curvatus KNOUC4148

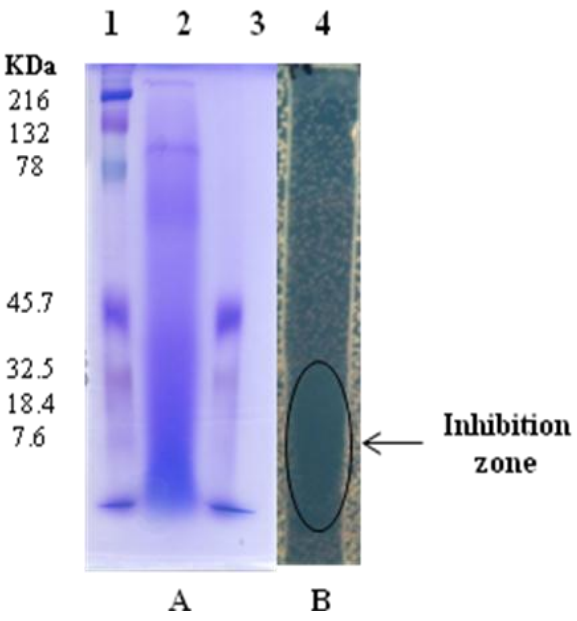

A. Gel stained with Coomasssie Brilliant Blue G250.

1. molecular weight standards (broad range, BIO-RAD \#161-031)

2. cell free supernatant of Lactobacillus curvatus KNOUC4148

3. molecular weight standards (polypeptide SDS-PAGE standards, BIO-RAD \#161-0326)

B. Gel overlaid with Muller Hinton agar containing indicator organism, Listeria monocytogenes. Inhibition zone formed by the antimicrobial substance in cell free supernatant of Lactobacillus curvatus KNOUC4148 is indicated by an arrow

The bacteriocins of $L b$. plantarum (Hernnadez et al., 2005) and Lb. sp.(Vinod et al., 2006) lost $25 \%$ and $60 \%$ of antimicrobial activity in $30 \mathrm{~min}$ and $20 \mathrm{~min}$ respectively at $100{ }^{\circ} \mathrm{C}$, and both of them were inactivated completely by autoclaving at $121{ }^{\circ} \mathrm{C}$. The antimicrobial substance of isolate KNOUC4148 did not lost its activity at the treatment at $\mathrm{pH} 4$ to 8 for $1 \mathrm{~h}$ at $37^{\circ} \mathrm{C}($ Table 3$)$, showing that acidic and neutral environment is safe for the antimicrobial substance of strain KNOUC4148. Hydrolysis of antimicrobial substance produced by isolate KNOUC4148 in cell free culture supernatant with protease $\mathrm{K}$ and trypsin extinguished all the antimicrobial activity(Table 3), indicating that the antimicrobial substance is a proteinaceous one and it would be a bacteriocin. Proteolytic hydrolysis inactivated the bacteriocin of $L b$. curvatus SE1(Kim et al., 1998) and pediocins PA-
1(Albano et al., 2007). As in Table 3, $\alpha$ Amylase hydrolysis inactivated the antimicrobial substance of isolate KNOUC4148, suggesting that amylolytic moiety of the antimicrobial substance may have an essential function on inhibitory activity. Bacteriocin of $L b$. curvatus SE1 was not affected by $\alpha$-amylase, but lost its antimicrobial activity by glucoamylase hydrolysis(Kim et al., 1998).

\section{Confirmation of Antimicrobial Substance on SDS-PAGE Gel}

Cell free culture supernatant of isolate KNOUC4148 was analyzed on SDS-PAGE to confirm the existence of antimicrobial proteineous substance. The substance showed antimicrobial activity to Listeria monocytogenes at the region around 7-18 $\mathrm{kDa}$ on SDS-PAGE gel (Figure 5). The gel stained by Coomassie brilliant blue showed 
main protein band at the same region with antimicrobial band. The $\mathrm{Mw}$ of bacteriocins produced by two strains of $L b$. curvatus were differently reported to be 4.07 $\mathrm{kDa}($ Garver and Muriana, 1994) and 6.257 kDa (Mohankumar and Arumugam, 2012).

\section{References}

Aasen, I.M., S. Markussen, T. Moretro, T. Katla, L. Axelsson and K. Naterstad. 2003. Interactions of the bacteriocins sakacin $\mathrm{P}$ and nicin with food constituents. Int. J. Food Microbiol. 87(1) : 35 - 43.

Albano, H., S. D. Todorov, C. A. VAN Reenen, T. Hogg, L. M. Dicks and P. Teixeira. 2007. Characterization of two bacteriocins produced by Pediococcus acidilactici isolated from "Alheira", a fermented sausage traditionally produced in Portugal. Int. J. Food Microbiol. 116(2) : 239 247.

Bhunia, A. K., M. C. Johnson and B. Ray. 1987. Direct detection of an antimicrobial of Pediococcus acidilactici in sodium dodecyl sulphate-polyacrylamide gel electrophoresis. J. Ind. Microbiol. Biotechnol. 2(2) : 319 - 322.

Casla, D., T. Requena and R. Gómez. 1996. Antimicrobial activity of lactic acid bacteria isolated from goat's milk and artisanal cheeses: characteristics of bacteriocin produced by Lactobacillus curvatus IFPL 105. J. Appl. Bacteriol. 81(1) : 35 - 41.

Han, E.J., N.K. Lee, S.Y. Choi and H.D. Paik. 2013. Short communication: Bacteriocin $\mathrm{KC} 24$ produced by Lactococcus lactis $\mathrm{KC} 24$ from kimchi and its antilisterial effect in UHT milk. J. Dairy Sci. 96(1) : 101 104.
Garver, K. I. and P. M. Muriana. 1994. Purification and partial amino acid sequence of curvaticin FS47, a heatstable bacteriocin produced by Lactobacillus curvatus FS47. Appl. Environ. Microbiol. 60(6) : 2191 2195.

Gunn, J. S. 2000. Mechanisms of bacterial resistance and response to bile. Microbes Infect. 2(7) : 907 - 913.

Ha, D. M., D. S. Cha and S. G. Han. 1994. Identification of bacteriocin producing lactic acid bacteria from kimchi and partial characterization of their bacteriocins. J. Microbiol. Biotechnol. 4(4) : 305 - 315.

Hernnadez, D., E. Cardell and V. Zarate. 2005. Antimicrobial activity of lactic acid bacteria isolation from Tenerife cheese: Initial characterization of plantaricin TF711 a bacteriocin-like substance produced by Lactobacillus plantarum TF711. J. Appl. Microbiol. 99(1) : 77 - 84.

Holt, J. G., N. R. Krieg, P. H. A. Sneath, J. T. Staley and S. T. Williams. 1994. Bergey's Manual of Determinative Bacteriology, $9^{\text {th }}$ edn. Baltimore, USA: Williams and Wilkins.

Kiely, L. J. and N. F. Olson. 2000. The physicochemical surface characteristics of Lactobacillus casei. Food Microbiol. 17(3) : 277 291.

Kim, D. H. and Y. H. Jin. 2001. Intestinal bacterial beta-glucuronidase activity of patients with colon cancer. Arch. Pharm. Res. 24(6) : 564 - 567.

Kim, E. K., S. Y. An, M. S. Lee, T. H. Kim, H. K. Lee, W. S. Hwang, S. J. Choe, T. Y. Kim, S. J. Han, H. J. Kim, D. J. Kim and K.W. Lee. 2011. Fermented kimchi reduces body weight and improves metabolic parameters in overweight and obese patients. Nutr. Res. $31: 436$ - 443. 
Kim, S. K., E. J. Lee, K. Y. Park and H. K. Jun. 1998. Bacteriocin produced by Lactobacillus curvatus SE1 isolated from kimchi. J. Microbiol. Biotechnol. 8(6) : 588 - 594.

Leroy, F. and L. De Vuyst. 1999. The presence of salt and a curing agent reduces bacteriocin production of Lactobacillus sakei CTC 494, a potential starter culture for sausage fermentation. Appl. Environ. Microbiol. 65(12) : 5350 - 5356.

Lui, M., A. Nauta, C. Francke and R.J. Siezen. 2008. Comparative genomics of enzymes in flavor-forming pathways from amino acids in lactic acid bacteria. Appl. Environ. Microbiol. 74(15) : 4590 - 4600.

Mataragas, M., J. Metaxopoulos and E. A. Drosinos. 2002. Characterization of two bacteriocins produced by Leuconostoc mesenteroides L124 and Lactobacillus curvatus L442, isolated from dry fermented sausages. World J. Microbiol. Biotechnol. 18(1) : 847 - 856.

Mohankumar, A. and S. Arumugam. 2012. Assay of a novel antimicrobial peptide Curvacin a produced by Lactobacillus curvatus isolated from fermented food products and its molecular characterization. Int. J. Appl. Biores. 6(1) : 35 - 39.

Morelli, L. 2000. In vitro selection of probiotic lactobacilli: a critical appraisal. Curr. Iss. Intest. Microbiol. $1(2): 59-67$.

Naidu, A.S., W.R. Bidlak and R.A. Clemens. 1999. Probiotic spectra of lactic acid bacteria (LAB). Cri. Rev. Food Sci. Nutr. 38(1) : 13 - 126.

Rainey, F. A., N. Ward-Rainey, R. M. Kroppenstedt and E. Stackebrandt. 1996. The genus Nocardiopsis represents a phylogenetically coherent taxon and a distinct actinomycete lineage: proposal of Nocardiopsacease fam. nov. Int. J. Syst. Bacteriol. 46(4) : 1088 - 1092.

Ram, C. and H. Chander. 2003. Optimization of culture conditions of probiotic bifidobacteria for maximal adhesion to hexadecane. World J. Microbiol. Biotechnol. 19(4) : 407 410.

Ross, R.P., S. Morgan and C. Hill. 2002. Preservation and fermentation: past: present and future. Int. J. Food Microbiol. 79(1) : 3 - 16 .

Saitou, N. and M. Nei. 1987. The neighborjoining method: a new method for reconstructing phylogenetic trees. Mol. Biol. Evol. 4(4) : 406 - 425.

Schagger, H. and G. Von Jagow. 1987. Tricine-sodium dodecyl sulphatepolyacrilamide gel electrophoresis for the separation of proteins in the range of 1 to $100 \mathrm{kDa}$. Anal. Biochem. 166(2) : 368 - 379.

Schar-Zammaretti, P. and J. Ubbink. 2003. The cell wall of lactic acid bacteria: surface constituents and macromolecular conformations. Biophys. J. 85(6) : 4076 - 4092.

Sudirman, I., F. Mathieu, M. Michel and G. Lefebvre. 1993. Detection and properties of curvaticin 13, a bacteriocin-like substance produced by Lactobacillus curvatus SB13. Curr. Microbiol. 27(1) : 35 - 40.

Summanen, P., H. M. Wexler and S.M. Finegold. 1992. Antimicrobial susceptibility testing of Bilophila wadsworthia by using triphenyltetrazolium chloride to facilitate endpoint determination. Antimicrob. Agents Chemother. 36 : 1658 - 1664.

Tichaczek, P. S., J. R. Meyer, I. F. Nes, R. F. Vogel and W. P. Hammes. 1992. Characterization of the bacteriocins curvacin A from Lactobacillus 
curvatus LTH 1174 and sakacin P from L. sake LTH 673. Syst. Appl. Microbiol. 15(3) : 460 - 468.

Todorov, S.D., D.N. Furtado, S.M.I. Saad, E. Tome and B.D.G.M. Franco. 2011. Potential beneficial properties of bacteriocin-producing lactic acid bacteria isolated from smoked salmon. J. Appl. Microbiol. 110(4) : 971 - 986.

Verluyten, J., W. Messens and L. De Vuyst. 2004. Sodium chloride reduces production of curvacin A, a bacteriocin produced by Lactobacillus curvatus strain LTH 1174, originating from fermented sausage. Appl. Environ. Microbiol. 70(4) : 2271 - 2278.

Vinod, K. J., S. Somesh and S. R. Neerja. 2006. Production, purification, stability and efficacy of bacteriocin from isolates of natural lactic acid fermentation of vegetables. Food Technol. Biotechnol. 44(3) : 435 439.

Walker, D. R. and S. E. Gilliland. 1993. Relationship among bile tolerance, bile salt deconjugation, and assimilation of cholesterol by Lactobacillus acidophilus. J. Dairy Sci. 76(4) : 956 - 961.

\section{How to cite this article:}

E. S. Nam and J. K. Ahn. 2016. Isolation of Lactobacillus curvatus KNOUC4148 from Kimchi and Its Properties as a Probiotic. Int.J.Curr.Microbiol.App.Sci.5(2): 284-296. doi: http://dx.doi.org/10.20546/ijcmas.2016.502.033 